\title{
Potentials of Lactic Acid Bacteria in Enhancing Nodulation of Bradyrhizobium daqingense and Yield in Soybean
}

\author{
Nakul Kale', M. Ashwini', Shamarao Jahagirdar², Geeta Shirnalli'
}

$10.18805 /$ LR-4639

\begin{abstract}
Background: The ferments of lactic acid bacteria ( $L A B)$ are used since decades in agricultural practice to control diseases, to promote plant growth and also to improve soils. However the functional roles of LAB in phytomicrobiome need to be discovered, which would result in understanding of the symbiotic relationship between LAB and plants and that could be exploited to improve agricultural production.

Methods: In this study, the scientific investigation was carried out for pot culture evaluation of six efficient LAB isolates from soybean rhizosphere, on nodulation and yield of soybean in green house condition, which were proven positive for IAA and GA production and PGPR traits.

Result: Among the eight different treatment combination with Bradyrhizobium daqingense the treatment which received consortium of all six $L A B$ isolates had significant impact on plant growth characters viz. plant height, root length, number of branches and chlorophyll content at 30 and 60 DAS. The LAB consortia also showed significantly high nodule number (47.67), nodule dry weight (117 mg plant $\left.{ }^{-1}\right)$ and leg haemoglobin content $\left(6.27 \mathrm{mg} \mathrm{g}^{-1}\right.$ fresh nodule) at 30 DAS. The yield and yield related traits was also highest in consortium treated plants. The property of plant to produce more nodules and healthy root growth can be attributed to IAA producing ability of inoculated LAB isolates.
\end{abstract}

Key words: Co-inoculation, Lactic acid bacteria, Nodulation.

\section{INTRODUCTION}

The plant growth-promoting rhizobacteria (PGPR) that live in rhizosphere occupy approximately 5 to $17 \%$ of the total root surface (Gray and Smith, 2005). The most widely studied genera include Rhizobium, Pseudomonas, Bacillus and Azospirillum. These microorganisms have beneficial effects on seed germination, seedling emergence and plant growth (Ahmad et al. 2008). According to Richardson et al. (2009), the interactions between plant roots and soil microbiota play a significant role in plant nutrition. Soil microorganisms promote plant growth through synthesis of plant hormones (auxins and gibberellins), nitrogen fixation, solubilization of inorganic phosphate and mineralization of organic phosphate, thus making these elements available to plants (Rodriguez and Fraga, 1999). These organisms also have beneficial effects on legume growth and some strains enhance nodulation and nitrogen fixation by affecting interactions between plant and rhizobia (Parmar and Dadarwal, 1999). With this background scientific study in improving nodulation efficiency of symbiotic Bradyhizobium sp. in legumes by co-inoculation was carried to combat excess use of chemical $\mathrm{N}$ fertilizers, for cost effective cultivation. The above mentioned context of improved nodulation is favoured by production of flavonoid like compounds or by stimulating the host legume to produce flavonoid signal molecule (Pankaj et al., 2009). As per the scientific evidences one of the important phytohormone that is IAA has positive significant influence over lateral root formation and nodulation when produced at lower doses. This is proven in case of Arabidopsis thaliana (Overvoorde et al., 2010).
1Department of Agricultural Microbiology, College of Agriculture, University of Agricultural Sciences, Dharwad-580 005, Karnataka, India.

2Department of Plant Pathology, College of Agriculture, University of Agricultural Sciences, Dharwad-580 005, Karnataka, India.

Corresponding Author: Nakul Kale, Department of Agricultural Microbiology, College of Agriculture, University of Agricultural Sciences, Dharwad-580 005, Karnataka, India.

Email: shivajiputra1@gmail.com

How to cite this article: Kale, N., Ashwini, M., Jahagirdar, S., Shirnalli, G. (2021). Potentials of Lactic Acid Bacteria in Enhancing Nodulation of Bradyrhizobium daqingense and Yield in Soybean. Legume Research. DOI: 10.18805/LR-4639.

Submitted: 19-04-2021 Accepted: 20-10-2021 Online: 16-11-2021

Studies have also shown that many rhizosphere microorganisms are capable of synthesizing plant growth regulators in vitro. Sarwar and Kremer (1995) studied microorganisms in the rhizospheres of different plants and found that root-associated isolates were more efficient in terms of auxin production than non-associated isolates. It is estimated that $80 \%$ of bacteria isolated from the rhizosphere are able to produce IAA (Pereira et al. 2012).

The $L A B$ represent a group of gram positive genera like Lactobacillus, Lactococci, Leuconostoc, Pediococcus and Streptococcous. They are facultative anaerobic bacteria, which reside on substrates that are rich in carbohydrates and ferment them into organic acids. As per the scientific evidences, lactic acid bacteria (LAB) are being extensively 
used in food industries in preparing fermented food products. The property of producing organic acids and antimicrobial compounds by $L A B$ is used in bio preservation of food products in maintaining quality product. Studies related to application of LAB in agriculture are relatively less; however, in vitro studies related to growth stimulation and antimicrobial studies are being carried out.

Similarly in case of Effective microorganisms (EM), which is a commercial biofertilizer that contains a mixture of co-existing beneficial microorganisms, predominantly it consists of species of lactic acid bacteria, (Arshad and Rukhsana, 2010) up on application in mung bean (Vigna radiata L.) and soybean (Javaid and Mahmood, 2010), showed a significant increase in nodule number and biomass in legumes (Javaid, 2011).

The characteristic feature of LAB to produce indole acetic acid, plant growth promoting activities and their significant role in consortia gives us a new dimension to work over their efficiency in augmenting nodulation in legumes as co-inoculant.

\section{MATERIAL AND METHODS}

The present experiment was conducted at Department of Agricultural Microbiology, UAS, Dharwad and the entire study was conducted under green house condition during the year 2019-2020. From our previous studies, six LAB isolates which showed positive result for IAA and GA production viz, AL-44, AL-45, AL-48, AL-49, AL-58 and AL-59 were selected for the present investigation.

\section{Compatibility testing}

The compatibility among the above mentioned microbial strains was confirmed by following multi strain streaking method and then used in consortia (Fig 1).

\section{Germination test (roll towel technique)}

This was done by following the roll towel technique as per ISTA (Tinnin and Kirkpatrick, 1985). Seeds of soybean were washed with distilled water and used. As many as 400 seeds were used for each treatment. The seeds were dipped in cultures of selected strains of the LAB for $10 \mathrm{~min}$ and then placed on the germination papers and rolled.

\section{Pot culture and treatment details}

Earthen pots of $30 \mathrm{~cm}$ top diameter was filled with $10 \mathrm{~kg}$ soil. The soil in each pot was mixed with $0.26 \mathrm{~g}$ urea, $1.5 \mathrm{~g}$ SSP and 0.12g MOP to supply 40:80:25 Kg N:P $\mathrm{P}_{2} \mathrm{O}_{5}: \mathrm{K}_{2} \mathrm{O}$ per ha on soil weight basis as per the package of practices. Half of the $\mathrm{N}$ was applied at the time of sowing and remaining half was applied as top dressing after 30 days of sowing. Soybean cultivar used was DSb-21 in three replication and eight treatment combination using CRD design (Panse and Sukhatme, 1985). The levels of significance used in the ' $F$ ' and 't' test was $P=0.01$.

1) Treatment 1: Absolute control (POP only).

2) Treatment 2: POP + Lactic acid bacteria AL-44.

3) Treatment 3: POP + Lactic acid bacteria AL-45.
4) Treatment 4: POP + Lactic acid bacteria AL-48.

5) Treatment 5: POP + Lactic acid bacteria AL-49.

6) Treatment 6: POP + Lactic acid bacteria AL-58.

7) Treatment 7: POP + Lactic acid bacteria AL-59.

8) Treatment 8: POP + Lactic acid bacteria Consortium (AL44+AL-45+AL-48+AL-49+AL-58+AL-59).

POP : NPK @ $16 \mathrm{~kg} / \mathrm{ac} \mathrm{N}, 32 \mathrm{~kg} / \mathrm{ac} \mathrm{P}_{2} \mathrm{O}_{5}, 10 \mathrm{~kg} / \mathrm{ac} \mathrm{K}_{2} \mathrm{O}_{5}$, $\mathrm{ZnSO}_{4}-5 \mathrm{~kg} / \mathrm{ac}$, sulphur- $8 \mathrm{~kg} / \mathrm{ac}$, Bradyrhizobium daqingense - $500 \mathrm{~g} / 30 \mathrm{~kg}$ seeds. PSB (Pseudomonas striata) - $500 \mathrm{~g} / 30 \mathrm{~kg}$ seeds.

\section{Seed treatment}

The $100 \mathrm{ml}$ of Mann, De Rogosa and Sharpe broth was inoculated with pure culture of LAB isolates for mass multiplication and kept on shaker for 2 days at $100 \mathrm{rpm}$, at $32^{\circ} \mathrm{C}$ and after attaining a population of $10^{8} \mathrm{cfu}$ per $\mathrm{ml}$. This one $\mathrm{ml}$ broth culture was mixed with lignite powder at 1:3 ratio, which had Bradyrhizobium daquingense used for seed treatment along with gum for effective and uniform seed coating. In case of consortium, one $\mathrm{ml}$ of all six isolates containing $10^{8} \mathrm{CFU} / \mathrm{ml}$ were properly assorted and then used in carrier material in the above mentioned ratio for seed treatment.

\section{Observations}

a) Plant physiological observations were taken at 30 and 60 DAS, number of nodules and their weight at 30 DAS, dry matter accumulation at harvest by placingsamples in hot air oven at $70^{\circ} \mathrm{C}$ for $48 \mathrm{~h}$, number of branches per plant and Chlorophyll content at 30 and 60 DAS. Later using SPAD (Soil Plant Analysis Development) instrument. The leg
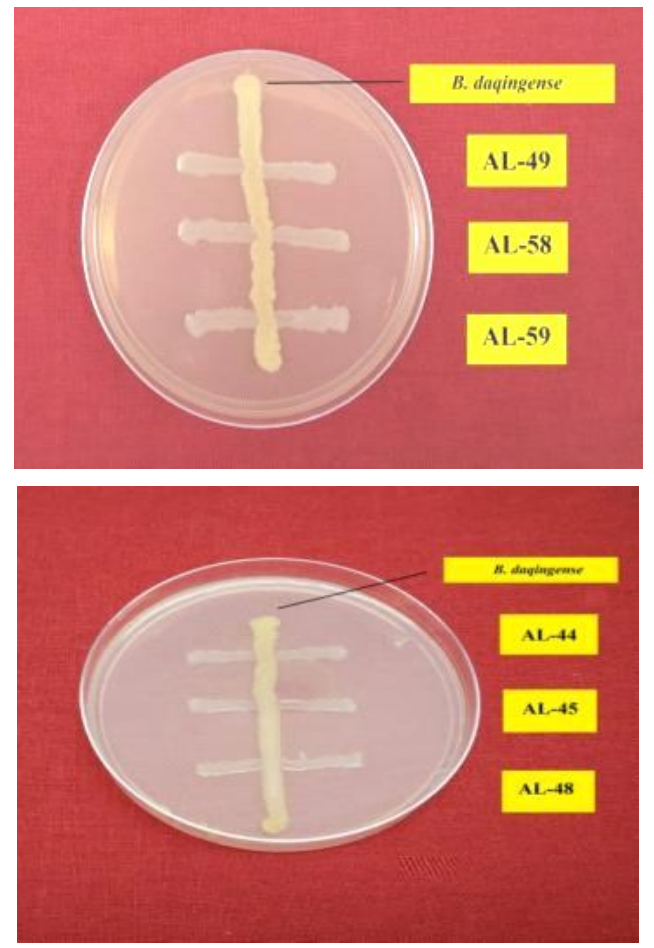

Fig 1: Compatibility test of efficient nodulation stimulating LAB isolates with Bradyrhizobium daqingense. 
haemoglobin content in nodules was quantified using drapkin solution at $254 \mathrm{~nm}$ at 30 DAS and yield parameters at harvest.

b) LAB, total free living $\mathrm{N}_{2}$ fixers and P-solubilizers count was taken by serial dilution of ten gram of soil up to $10^{-5}$ and plated on MRS agar media, Norris $\mathrm{N}$ free medium and Pikovskaya's medium respectively. Bacterial colonies thus formed were taken as total count for $L A B$ and $N_{2}$ fixers on respective media and zone of solubilization for P-solubilizers. c) Rhizosphere soil enzyme activities like Urease activity (Tabatabai and Bremner, 1972), Phosphatase activity (Evazi and Tabatabai, 1979) and Dehydrogenase activity (Casida et al. 1964) at peak stages.

d) Plant nutrient content at harvest was estimated for total Nitrogen by kjeldhal process (Tandon, 1998), phosphorus content by vanadomolybophosphoric yellow colour method (Tandon, 1998), potassium content by flame photometry method (Sparks, 1996).

\section{RESULTS AND DISCUSSION}

\section{Seedling vigour and compatibility}

Seed inoculation significantly enhanced seed germination and seedling vigour of soybean. The bacterial strain AL-59 increased seed germination up to $11 \%$ over nontreated

Table 1: Effect of selected efficient nodulation stimulating LAB isolates on seedling vigour of soybean.

\begin{tabular}{lcccc}
\hline Isolate & $\begin{array}{c}\text { Germination } \\
(\%)\end{array}$ & $\begin{array}{c}\text { Shoot length } \\
(\mathrm{cm})\end{array}$ & $\begin{array}{c}\text { Root length } \\
(\mathrm{cm})\end{array}$ & SVI \\
\hline Control & 84.67 & 4.0 & 3.5 & 0633.9 \\
AL-44 & 86.33 & 4.5 & 3.6 & 0704.8 \\
AL-45 & 93.33 & 6.1 & 4.8 & 1011.6 \\
AL-48 & 94.00 & 6.0 & 5.0 & 1037.7 \\
AL-49 & 87.00 & 4.7 & 4.2 & 0781.3 \\
AL-58 & 89.67 & 5.1 & 4.1 & 0825.8 \\
AL-59 & 95.67 & 6.7 & 5.4 & 1160.4 \\
S.Em. \pm & 1.19 & 0.18 & 0.28 & 40.62 \\
C.D. $(p=0.01)$ & 4.92 & 0.73 & 1.16 & 167.77 \\
\hline
\end{tabular}

control. The highest was noticed in AL-59 and AL-48 treated seeds, which recorded 1160.4 and 1037.7 vigour index respectively (Table 1 ).

\section{Plant physiological observations}

The co-inoculation of LAB had significant influence on plant physiological parameters at 30 and 60 DAS. The observations recorded in Table 2, clearly depicts that the treatment $\mathrm{T}_{8}(\mathrm{POP}+$ Consortium) showed highest plant height, root length, number of branches and chlorophyll content by $72 \mathrm{~cm}, 77.3 \mathrm{~cm}, 11.67$ and 42.4 respectively (Table 2) and similar trend was noticed at 60 DAS (Fig 2 and 3).

The phenomenon of enhanced root and shoot growth can be attributed to production of auxins and nutrient mineralisation by PGPR (Steenhoudt and Vanderleyden, 2000). Similar findings were observed by Overvoorde et al. (2010), who opined that IAA when produced at low concentration showed positive significant influence over lateral root formation.

\section{Nodulation}

Co-inoculation of Bradyrhizobium daqingense with LAB isolates significantly increased the number of nodule; Leg haemoglobin content and nodule dry weight per plant as compared to control. The highest number of nodules per plant was recorded in treatment $\mathrm{T}_{8}(\mathrm{POP}+$ Consortium) which scored 74.3 nodules per plant, which is $33.67 \%$ more than control (49.3), followed by $\mathrm{T}_{6}(\mathrm{POP}+\mathrm{AL}-58)$ with 65.7 nodule number (Table 3 ). The root scanning images (Fig 1) of uprooted plants at 30 DAS confirms the differential ability of consortium treated compared to other treatments in rooting and nodule bearing. Consequently the analysis for nodule dry weight is in accordance with nodule number, that highest nodule bearing consortium treated plants showed higher nodule dry weight of $117 \mathrm{mg}$. The analysis of leghaemoglobin content was done for one gram of fresh nodule extract using drapkin solution. The spectrophometric values at $254 \mathrm{~nm}$ reveals that, consortium treated plants produced more leghaemoglobin ( $6.21 \mathrm{mg} \mathrm{g}^{-1}$ fresh weight nodules) compared to control (2.98 $\mathrm{mg} \mathrm{g}^{-1}$ fresh weight nodules) (Table 3).

Table 2: Effect of efficient nodulation stimulating LAB isolates on plant growth characters and chlorophyll content at 30 and 60 DAS.

\begin{tabular}{|c|c|c|c|c|c|c|c|c|}
\hline \multirow[t]{2}{*}{ Treatments } & \multicolumn{2}{|c|}{$\begin{array}{l}\text { Plant height } \\
(\mathrm{cm})\end{array}$} & \multicolumn{2}{|c|}{$\begin{array}{l}\text { Root length } \\
(\mathrm{cm})\end{array}$} & \multicolumn{2}{|c|}{$\begin{array}{c}\text { No of } \\
\text { branches }\end{array}$} & \multicolumn{2}{|c|}{$\begin{array}{c}\text { Relative chlorophyll } \\
\text { content (SPAD values) }\end{array}$} \\
\hline & 30 DAS & 60 DAS & 30 DAS & 60 DAS & 30 DAS & 60 DAS & 30 DAS & 60 DAS \\
\hline $\mathrm{T}_{1}$ & 37.0 & 49.3 & 16.3 & 17.7 & 6.33 & 9.2 & 38.8 & 39.0 \\
\hline $\mathrm{T}_{2}$ & 42.7 & 53.0 & 23.0 & 23.3 & 8.00 & 10.2 & 42.1 & 42.0 \\
\hline $\mathrm{T}_{3}$ & 60.3 & 62.0 & 48.7 & 50.3 & 13.00 & 15.3 & 42.6 & 41.4 \\
\hline $\mathrm{T}_{4}$ & 62.3 & 64.7 & 32.7 & 36.3 & 9.67 & 13.8 & 42.0 & 40.7 \\
\hline $\mathrm{T}_{5}$ & 40.3 & 51.0 & 33.0 & 35.0 & 6.33 & 8.3 & 40.9 & 41.7 \\
\hline $\mathrm{T}_{6}$ & 61.7 & 65.7 & 44.7 & 51.3 & 10.00 & 14.1 & 40.3 & 41.9 \\
\hline $\mathrm{T}_{7}$ & 61.0 & 62.3 & 45.7 & 46.3 & 10.00 & 14.2 & 42.2 & 43.0 \\
\hline $\mathrm{T}_{8}$ & 72.0 & 74.3 & 77.3 & 82.7 & 11.67 & 17.8 & 42.4 & 44.0 \\
\hline S.Em. \pm & 1.7 & 1.0 & 1.7 & 5.2 & 0.42 & 0.9 & 0.50 & 0.50 \\
\hline C.D. $(p=0.01)$ & 6.9 & 4.1 & 6.8 & 21.6 & 1.76 & 3.5 & 2.09 & 2.00 \\
\hline
\end{tabular}

*UIC- Un -inoculated control. *DAS: Days after sowing. 
Many studies have shown that simultaneous infection with rhizobia and rhizospheric bacteria increases nodulation and growth in a wide variety of legumes (Bolton et al., 1990). Accumulation of lactic acid in root nodules at the time of nodule development in response to symbiotic $B$. japonicum (Laurent et al,. 2010) might favour the nodule development, this accumulation of lactic acid was previously reported to be abundant in alfalfa (Swaraj and
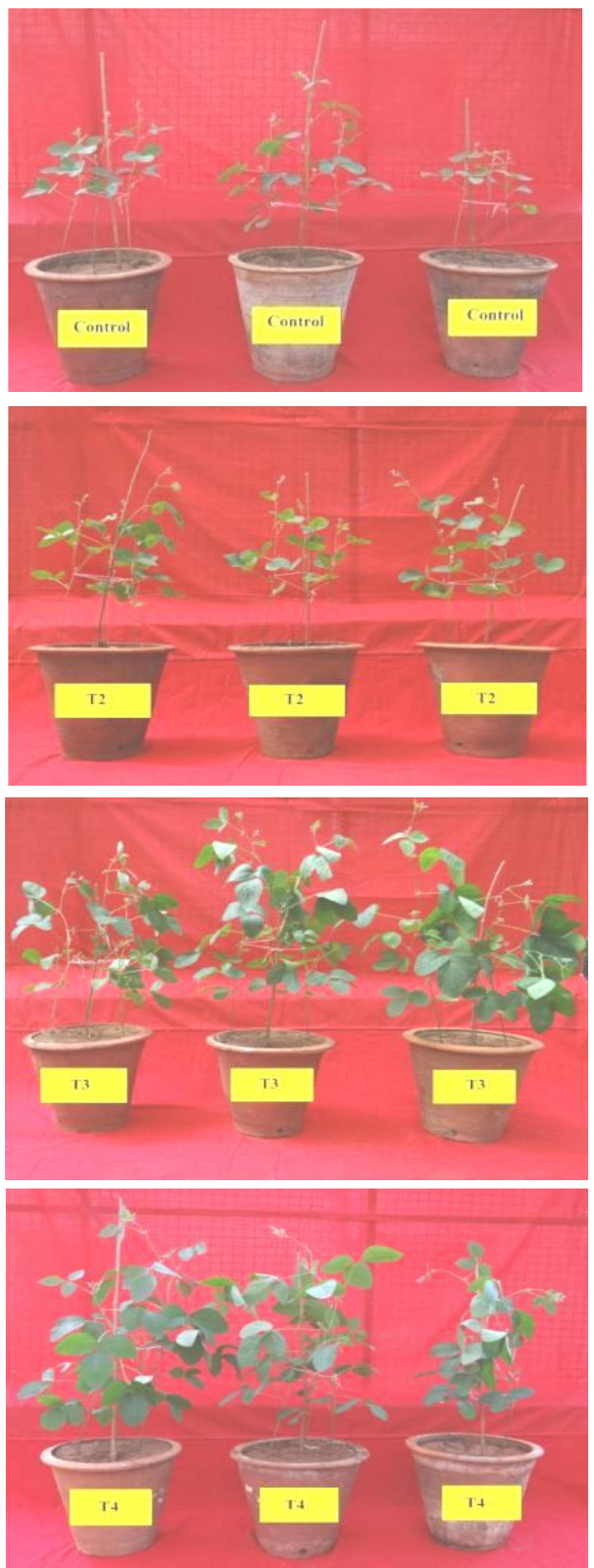

Fig 2: Comparison of effective nodulation stimulating LAB isolates with control at 30 DAS in pot culture study.
Bishnoi 1999; Barsch et al., 2006) and some lactic acid polymers have also shown to stimulate plant growth in corn and soybean (Kinnersley et al., 1990; Chang et al., 1996).

Here in this study application of lactic acid bacteria might have created favorable conditions for the nodulation and would have assisted the Bradyrhizobium in the process of root hairs infection, bacteriod development and might
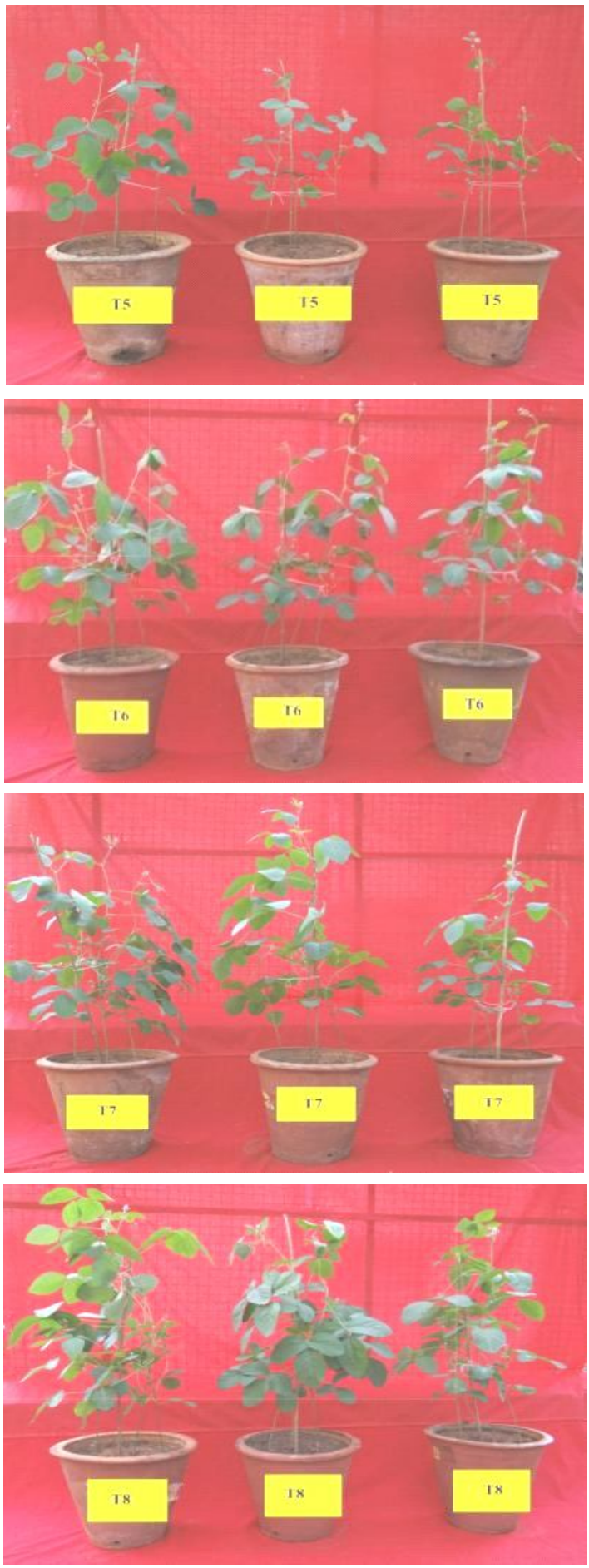

Legume Research - An International Journal 
have facilitated the nodule formation and development by producing phytoalexins or flavonoid compounds.

\section{Soil microbial analysis}

The soil microbial analysis was done at the time of flowering and harvest indirectly by computing the enzyme activities like urease, phosphatase and dehydrogenase activities in soil. The result showed that microbial activity with respect to production of above mentioned enzymes was relatively higher at the time of flowering compared to harvest stage. This might be due to differential release of root exudates at different plant growth stage, which will in turn act as carbon and energy source for the soil microbes. The flowering stage is one where there is no tillage activity in soybean, in this context (Gholamreza et al., 2016) showed highest microbial biomass carbon and recorded higher values of acid phosphatase, alkaline phosphatase and dehydrogenase activity. As far as treatment combinations are concerned, the one which received consortium $\left(\mathrm{T}_{8}\right)$ of all six isolates exhibited higher soil enzyme activity. Which scored $63.6(\mu \mathrm{g}$ $\mathrm{NH}_{4}-\mathrm{N} /$ Soil day ${ }^{-1}$ ) for urease activity, $700.24(\mu \mathrm{g} \mathrm{PNP/g}$ soil hour $^{-1}$ ) for phospphatase activity and 233.37 ( $\mu \mathrm{g}$ TPF/g soil

Table 3: Effect of LAB in augmenting nodulation of Bradhyrhizobium daquingense in soybean at 30 DAS.

\begin{tabular}{lccc}
\hline Treatments & $\begin{array}{c}\text { No. } \\
\text { of } \\
\text { nodules }\end{array}$ & $\begin{array}{c}\text { Nodule dry } \\
\text { weight } \\
(\mathrm{mg})\end{array}$ & $\begin{array}{c}\text { Leghaemoglobin } \\
\text { content }\left(\mathrm{mg} \mathrm{g}^{-1} \text { fresh }\right. \\
\text { weight nodules })\end{array}$ \\
\hline $\mathrm{T}_{1}$ & 14.33 & 037.3 & 2.98 \\
$\mathrm{~T}_{2}$ & 18.33 & 044.3 & 3.87 \\
$\mathrm{~T}_{3}$ & 32.00 & 097.9 & 5.79 \\
$\mathrm{~T}_{4}$ & 35.00 & 095.3 & 4.69 \\
$\mathrm{~T}_{5}$ & 18.00 & 039.7 & 4.03 \\
$\mathrm{~T}_{6}$ & 20.33 & 075.3 & 4.49 \\
$\mathrm{~T}_{7}$ & 39.33 & 098.3 & 4.44 \\
$\mathrm{~T}_{8}$ & 47.67 & 117.0 & 6.21 \\
S.Em. \pm & 0.93 & 3.64 & 0.35 \\
C.D. $(\mathrm{p}=0.01)$ & 3.83 & 15.0 & 1.43 \\
\hline
\end{tabular}

*UIC- Un inoculated control. *DAS: Days after sowing.
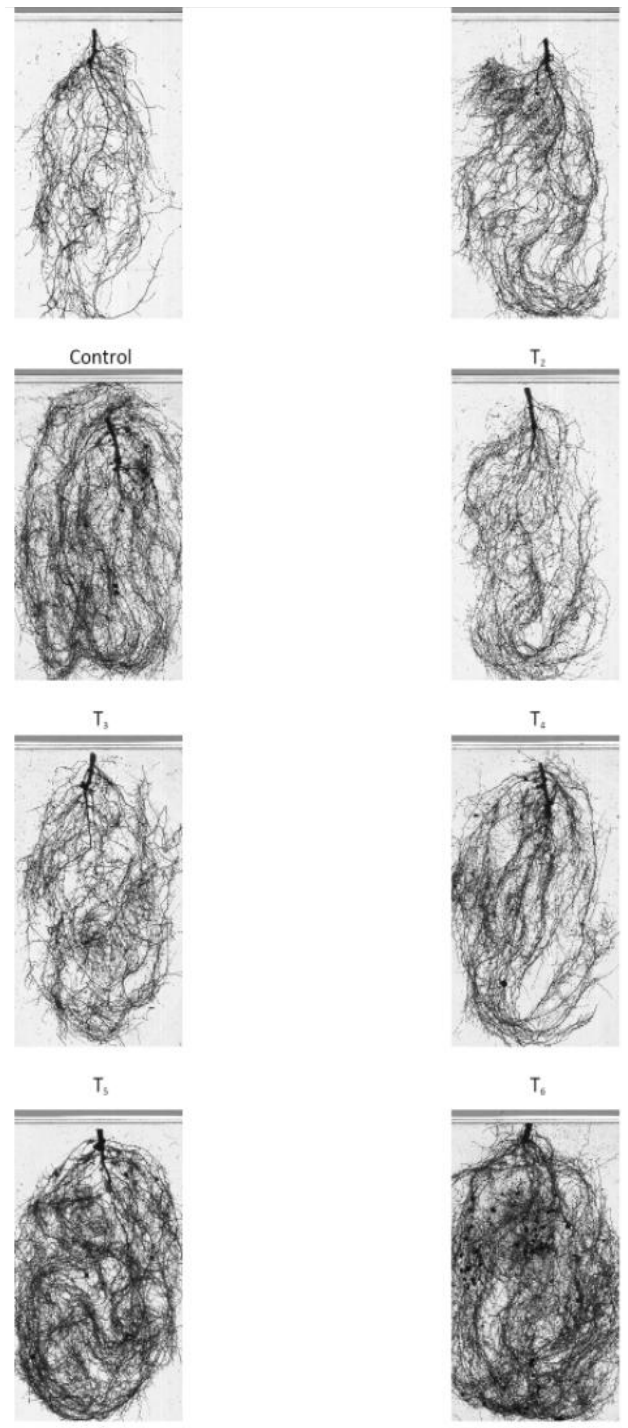

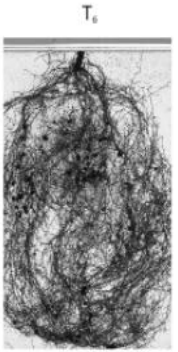

Fig 3: Root scanning images of efficient nodulation stimulating LAB isolates with control at 30DAS in pot culture study.

Table 4a: Influence of co-inoculation of LAB on soil enzyme activities at flowering and harvest.

\begin{tabular}{|c|c|c|c|c|c|c|}
\hline \multirow[t]{2}{*}{ Treatments } & \multicolumn{2}{|c|}{$\begin{array}{c}\text { Urease activity } \\
\left(\mu \mathrm{g} \mathrm{NH}_{4}-\mathrm{N} / \text { Soil day }{ }^{-1}\right)\end{array}$} & \multicolumn{2}{|c|}{$\begin{array}{l}\text { Phosphatase activity } \\
\left(\mu \mathrm{g} \text { PNP/g soil hour }{ }^{-1}\right)\end{array}$} & \multicolumn{2}{|c|}{$\begin{array}{l}\text { Dehydrogenase activity } \\
\left(\mu \mathrm{g} \text { TPF/g soil day }{ }^{-1}\right)\end{array}$} \\
\hline & At flowering & At harvest & At flowering & At harvest & At flowering & At harvest \\
\hline $\mathrm{T}_{1}$ & 23.43 & 10.38 & 313.60 & 271.95 & 074.46 & 066.07 \\
\hline $\mathrm{T}_{2}$ & 33.93 & 12.19 & 481.10 & 430.14 & 077.53 & 063.08 \\
\hline $\mathrm{T}_{3}$ & 39.83 & 17.91 & 575.00 & 524.83 & 179.52 & 159.85 \\
\hline $\mathrm{T}_{4}$ & 35.95 & 12.31 & 601.12 & 525.33 & 156.12 & 131.33 \\
\hline $\mathrm{T}_{5}$ & 27.31 & 12.67 & 557.48 & 507.74 & 126.56 & 107.85 \\
\hline $\mathrm{T}_{6}$ & 38.69 & 18.92 & 566.86 & 498.81 & 169.49 & 145.28 \\
\hline $\mathrm{T}_{7}$ & 47.29 & 20.33 & 612.73 & 544.67 & 182.50 & 156.95 \\
\hline $\mathrm{T}_{8}$ & 63.60 & 25.31 & 700.24 & 617.00 & 233.37 & 205.67 \\
\hline S.Em. \pm & 00.33 & 00.52 & 000.87 & 010.27 & 000.72 & 005.17 \\
\hline C.D. $(p=0.01)$ & 01.38 & 02.13 & 003.58 & 042.42 & 002.98 & 021.35 \\
\hline
\end{tabular}

*UIC- Un inoculated control. 
day $^{-1}$ ) for dehydrogenase activity. Similar tendency was noticed at harvest stage. However, enzyme activities were lower at harvest than flowering stage.

The persistence of seed inoculated microbes till to the harvest stage depicts their competitive ability to survive as free living organisms in absence symbiotic host. In this regard soil analysis was done to enumerate total free living $\mathrm{N}$ fixers using Norris $\mathrm{N}$ free agar medium, $\mathrm{P}$ solubilisers by

Table 4b: Soil microbial count at harvest.

\begin{tabular}{lccc}
\hline Treatments & $\begin{array}{c}\text { Free living N fixers } \\
\text { (CFU 10\% } \\
\text { Soil) }\end{array}$ & $\begin{array}{c}\text { PSB } \\
\text { (CFU 10 } / \mathrm{g} \\
\text { Soil) }\end{array}$ & $\begin{array}{c}\text { LAB count } \\
\text { (CFU 106/g } \\
\text { Soil) }\end{array}$ \\
\hline $\mathrm{T}_{1}$ & 9.7 & 11.0 & 00.6 \\
$\mathrm{~T}_{2}$ & 10.3 & 12.3 & 19.0 \\
$\mathrm{~T}_{3}$ & 12.7 & 18.0 & 19.7 \\
$\mathrm{~T}_{4}$ & 11.7 & 18.1 & 17.0 \\
$\mathrm{~T}_{5}$ & 10.0 & 12.7 & 20.7 \\
$\mathrm{~T}_{6}$ & 12.3 & 13.3 & 20.7 \\
$\mathrm{~T}_{7}$ & 12.7 & 12.0 & 22.3 \\
$\mathrm{~T}_{8}$ & 13.3 & 17.3 & 27.3 \\
S.Em. \pm & 0.8 & 0.8 & 1.0 \\
C.D. $(\mathrm{p}=0.01)$ & 3.3 & 3.4 & 4.3 \\
\hline
\end{tabular}

*UIC- Un inoculated control. * PSB- Phosphorus solubilizing bacteria
Pikovaskaya agar medium and LAB count using MRS agar medium. The results depicted that, all treatments showed the existence of above mentioned microbes. However, their number varied among the treatments and the highest enumeration was recorded in consortium treated $\left(\mathrm{T}_{8}\right)$ soil (Table $4 \mathrm{a}, \mathrm{b}$ ).

\section{Plant nutrient concentration and yield}

The values represented in Table $5(\mathrm{a}, \mathrm{b})$ clearly dipicts that $\mathrm{T}_{8}$ (POP+Consortium) showed highest $\mathrm{N}, \mathrm{P}$ and $\mathrm{K}$ uptake, which is represented in terms of percentage as $3.68 \%$, $0.22 \%$ and $2.03 \%$ respectively. The micronutrient analysis was done for $\mathrm{Cu}, \mathrm{Zn}, \mathrm{Fe}$ and $\mathrm{Mn}$ at harvest for all the treatments. In all cases $\mathrm{T}_{8}(\mathrm{POP}+\mathrm{Consortium)}$ showed maximum up take for $\mathrm{Cu}, \mathrm{Zn}$, Fe and $\mathrm{Mn}$ up take by 94.8 , 207.7, 984.7 and 95.4 ppm respectively.

Kang et al., (2015) investigated the effects of three potential members of an EM consortia, Rhodobacter sphaeroides, Saccharo-myces cerevisiaeand and Lactobacillus plantarumon the growth and development of cucumber. All three microorganisms increased growth, nutrient uptake, amino acid content and yield. The increased availability of nutrients to plant might be due to the increased nodule number for $\mathrm{N}$ uptake through $\mathrm{N}$ fixation, production of lactic acid for $\mathrm{P}$ and $\mathrm{Zn}$ solubilisation, production of

Table 5a: Plant nutrient content at harvest as influenced by LAB inoculum.

\begin{tabular}{lccccccc}
\hline Treatments & $\mathrm{N}(\%)$ & $\mathrm{P}(\%)$ & $\mathrm{K}(\%)$ & $\mathrm{Cu}(\mathrm{ppm})$ & $\mathrm{Zn}(\mathrm{ppm})$ & $\mathrm{Fe}(\mathrm{ppm})$ & $\mathrm{Mn}(\mathrm{ppm})$ \\
\hline $\mathrm{T}_{1}$ & 0.25 & 0.16 & 0.35 & 19.4 & 26.1 & 427.6 & 42.2 \\
$\mathrm{~T}_{2}$ & 0.63 & 0.17 & 1.58 & 22.2 & 30.9 & 451.1 & 52.3 \\
$\mathrm{~T}_{3}$ & 0.80 & 0.17 & 1.71 & 42.8 & 40.9 & 977.7 & 89.5 \\
$\mathrm{~T}_{4}$ & 0.78 & 0.17 & 1.40 & 26.1 & 36.9 & 569.6 & 73.4 \\
$\mathrm{~T}_{5}$ & 0.70 & 0.18 & 1.11 & 32.2 & 38.1 & 448.8 & 63.9 \\
$\mathrm{~T}_{6}$ & 0.59 & 0.17 & 1.72 & 35.4 & 40.3 & 575.0 & 64.3 \\
$\mathrm{~T}_{7}$ & 0.88 & 0.19 & 1.80 & 46.6 & 60.6 & 846.2 & 83.4 \\
$\mathrm{~T}_{8}$ & 3.68 & 0.22 & 2.03 & 94.8 & 207.7 & 984.7 & 95.4 \\
S.Em. \pm & 0.10 & 0.002 & 0.02 & 01.4 & 001.6 & 006.3 & 01.4 \\
C.D. $(\mathrm{p}=0.01)$ & 0.42 & 0.009 & 0.12 & 05.9 & 006.6 & 026.2 & 05.6 \\
\hline
\end{tabular}

*UIC- Un inoculated control.

Table 5b: Effect of efficient nodulation stimulating LAB isolates on yield and yield components of soybean at harvest.

\begin{tabular}{|c|c|c|c|c|c|c|}
\hline Treatments & $\begin{array}{c}\text { Pods per } \\
\text { plant }\end{array}$ & $\begin{array}{l}\text { Seeds per } \\
\text { pod }\end{array}$ & $\begin{array}{c}\text { Yield per plant } \\
\text { in }(\mathrm{g})\end{array}$ & $\begin{array}{l}\text { Shoot dry } \\
\text { weight }(g)\end{array}$ & $\begin{array}{l}\text { Root dry } \\
\text { weight }(g)\end{array}$ & $\begin{array}{l}\text { Total dry } \\
\text { weight }(\mathrm{g})\end{array}$ \\
\hline $\mathrm{T}_{1}$ & 05.20 & 2.00 & 03.80 & 2.95 & 0.50 & 07.25 \\
\hline $\mathrm{T}_{2}$ & 06.10 & 2.33 & 07.57 & 3.43 & 0.67 & 11.67 \\
\hline $\mathrm{T}_{3}$ & 09.67 & 2.23 & 11.77 & 1.26 & 0.97 & 14.00 \\
\hline $\mathrm{T}_{4}$ & 11.77 & 2.33 & 10.83 & 1.41 & 0.83 & 13.07 \\
\hline $\mathrm{T}_{5}$ & 10.33 & 2.00 & 08.53 & 4.03 & 0.77 & 13.33 \\
\hline $\mathrm{T}_{6}$ & 07.77 & 2.10 & 14.00 & 1.74 & 0.93 & 16.67 \\
\hline $\mathrm{T}_{7}$ & 13.10 & 2.20 & 13.67 & 3.36 & 1.27 & 19.30 \\
\hline $\mathrm{T}_{8}$ & 18.47 & 3.00 & 18.33 & 4.36 & 1.97 & 23.67 \\
\hline S.Em. \pm & 0.58 & & 0.74 & & 0.06 & 0.50 \\
\hline C.D. $(p=0.01)$ & 2.39 & & 3.04 & & 0.24 & 2.05 \\
\hline
\end{tabular}

*UIC- Un inoculated control. 
siderophores for Fe uptake and proliferated root growth for quenching other nutrients in soil.

\section{CONCLUSION}

The $L A B$ isolated from soybean rhizosphere have proven from the above evidences that, the property of $L A B$ isolates to produce growth promoters like IAA and GA has interacted synergistically in augmenting nodulation of $B$. daqingense. The root scanning images clearly depicts profuse growth of root hairs in LAB treated soybean, this is more promising in $\mathrm{LAB}$ consortium treated plants compared to control. Healthy root and nodule growth has favoured plant to interact more with available nutrients in soil and has given more grain yield.

\section{REFERENCES}

Ahmad, F., Ahmad, I. and Khan, M.S. (2008). Screening of freeliving rhizospheric bacteria for their multiple plant growth promoting activities. Microbiological Research. 81: 163-173.

Arshad, J. and Rukhsana, B. (2010). Field evaluation of effective microorganisms (EM) application for growth, nodulation, and nutrition of mung bean. Turkish Journal of Agriculture and Forestry. 35: 443-452.

Barsch, A., Tellstrom, V., Patschkowski, T.K.H. and Niehaus, K. (2006). Metabolite profiles of nodulated alfalfa plants indicate that distinct stages of nodule organogenesis are accompanied by global physiological adaptations. Molecular Plant-Microbe Interactions. 19: 998-1013.

Bolton, H., Elliott, L.F., Turco, R.F. and Kennedy, A.C. (1990). Rhizoplane colonization of pea seedlings by Rhizobium leguminosarum and a deleterious root colonizing Pseudomonas spp. and effects on plant growth. Plant Soil. 123: 121-124.

Casida, L.E., Klein, D.A. and Santaro, T. (1964). Soil dehydrogenase activity. Soil Science. 98: 371-376.

Chang, Y.N., Mueller, R.E. and lannotti, E.L. (1996). Use of low MW polylactic acid and lactide to stimulate growth and yield of soybeans. Plant Growth Regulation. 19: 223-232.

Evazi, Z. and Tabatabai, M.A. (1979). Phosphatase in soils. Soil Biology and Biochemistry. 9: 167-172.

Gholamreza, H., Khosro, M. and Yousef, S. (2016). Responses of Soil Microbial Biomass and Enzyme Activities to Tillage and Fertilization Systems in Soybean (Glycine max L.) Production. Frontiers in Plant Science. 7: 1730.

Gray, E.J. and Smith, D.L. (2005). Intracellular and extracellular PGPR: commonalities and distinctions in the plant-bacterium signaling processes. Soil Biology and Biochemistry. 37: 395-412.

Javaid, A. (2011). Effects of biofertilizers combined with different soil amendments on potted rice plants. Chilean Journal of Agricultural. 71: 157-163.

Javaid, A. and Mahmood, N. (2010). Growth, nodulation and yield response of soybean to biofertilizers and organic manures. Pakistan Journal of Botany. 42: 863-871.

Kang, S.M., Radhakrishnan, R., You, Y.H., Khan, A.L., Park, J.M., Lee, S.M. and Lee, I.J., (2015). Cucumber performance is improved by inoculation with plant growth promoting microorganisms. Acta Agriculturae Scandinavica, Section B dsoil and Plant Science. 65: 36-44.
Kinnersley, A.M., Scott, T.C., Yopp, J.H. and Whitten, G.H. (1990). Promotion of plant growth by polymers of lactic acid. Plant Growth Regulation. 9: 137-146.

Laurent, B., Zhentian, L., Marc, L., Seth, F., Masayuki, S., Michael, J.S., Lloyd, W., Sumner and Gary, S. (2010). Soybean metabolites regulated in root hairs in response to the symbiotic bacterium Bradyrhizobium japonicum. Plant Physiology. 153: 1808-1822.

Overvoorde, P., Fukaki, H. and Beeckman, T. (2010). Auxin control of root development. Cold Spring Harbor Perspectives in Biology. 2: 1537.

Pankaj, K.M., Smita. M., Selvakumar, G., Samresh, K. and Hari, S.G. (2009). Enhanced soybean (Glycinemax L.) plant growth and nodulation by Bradyrhizobium japonicum-SB1 in presence of Bacillus thuringiensis-KR1. Acta Agriculturae Scandinavica, Section B - Soil and Plant Science. 59: 189-196.

Panse, V.G. and Sukhatme, P.V. (1985). Statistical Methods for Agricultural Workers, $4^{\text {th }}$ Ed., ICAR, New Delhi (India) pp. 347.

Parmar, N. and Dadarwal, K.R. (1999). Stimulation of nitrogen fixation and induction of flavonoid-like compounds by rhizobacteria. Journal of Applied Microbiology. 86: 3664.

Pereira, A.P.A., Silva, M.C.B., Oliveira, J.R.S., Ramos, A.P.S., Freire, M.B.G.S. and Freire, F.J. (2012). Influência da salinidade sobre o crescimento e a produção de ácido indolacético de Burkholderia spp. endofíticas de cana-de-açúcar. Bioscience Journal. 21: 28-112.

Richardson, A.E., Barea, J.M., Mcneill, A.M. and Prigent-Combaret, C. (2009). Acquisition of phosphorus and nitrogen in the rhizosphere and plant growth promotion by microorganisms. Plant Soil. 39: 305-321.

Rodríguez, H. and Fraga, R. (1999). Phosphate solubilizing bacteria and their role in plant growth promotion. Biotechnology Advances. 17: 319-324.

Sarwar, R.M. and Kremer, R.J. (1995). Enhanced suppression of plant growth through production of L-tryptophan-derived compounds by deleterious rhizobacteria. Plant Soil. 69: 172-261.

Sparks, H. (1996). Methods of Soil Analysis Part- 3: Chemical Methods. Soil Science Society of America, USA pp. 3238.

Steenhoudt, O. and Vanderleyden, J. (2000). Azospirillum, a freeliving nitrogen-fixing bacterium closely associated with grasses: Genetic, biochemical and ecological aspects. FEMS Microbiology Reviews. 24: 487-506.

Swaraj, K. and Bishnoi, N.R. (1999). Effect of salt stress on nodulation and nitrogen fixation in legumes. Indian Journal of Experimental Biology. 37: 843-848.

Tabatabai, M.A. and Bremner, J.M. (1972). Assay of urease activity in soils. Soil Biology and Biochemistry. 4: 479-487.

Tandon, H.L.S. (1998). Methods of Analysis of Soils, Plants, Water and Fertilizers. Fertilizer Development and Consultation Organization, New Delhi pp.78-82.

Tinnin, R.O., Kirkpatrick, L.A. (1985). The allelopathic influence of broad leaf trees and shrubs on seedlings of douglas-fir. Forest Science. 31: 945-952. 